como "estado beligerante"; y sabemos finalmente que luego de la apertura de un frente militar en la provincia de Tucumán, concibió a aquel territorio como "zona liberada".

Como ha quedado demostrado en los fundamentos de querellantes, fiscales y jueces en las distintas instancias de la causa Larrabure, del análisis de estos datos, de su interpretación, depende, en buena medida, la resolución de la causa.

Para que la causa Larrabure sea considerada imprescriptible, la muerte del militar debe quedar inscripta en la categoría de "crimen de lesa humanidad en el contexto de conflicto armado interno". A tal fin, la querella debe demostrar que en la Argentina de los años setenta hubo una guerra, que el ERP constituyó uno de los ejércitos regulares enfrentados en esa guerra, y que, además, controlaba territorio y población. Y es aquí, entonces, donde nos encontramos, no sin sorpresa, con una interesante paradoja. Las fuentes en las que se basa la querella en su fundamentación están compuestas, en porcentaje mínimo, por la propia documentación partidaria y, en un porcentaje notoriamente mayor, por la obra de un reconocido historiador del PRT-ERP, Pablo Pozzi, a quien de ninguna manera podría considerarse ni remotamente aliado de la querella. El problema es que, más allá de la reconstrucción particular de la experiencia perretista que Pozzi ofrece y su ponderación, más allá de su propia voluntad incluso, el tono general de la obra no logra trascender el sistema partidario de creencias. Los testimonios allí reproducidos, abundantes en guiños de complicidad y escasos en confrontación crítica, empujan a una narrativa que no deja de hacerse eco de las proyecciones imaginarias de los propios actores. $Y$ entonces, nos encontramos ante un PRT-ERP con una influencia de masas y una capacidad política y militar un tanto sobredimensionadas, incluso en Tucumán, donde, según "un informe de la Fuerza Aérea norteamericana", mencionado pero nunca confrontado por Pozzi, el ERP controlaba un tercio del territorio. Y es ahí donde la querella echa mano de la autoridad del historiador y ofrece como prueba histórica lo que no es más que imaginario.

En contraposición, sólo un abordaje crítico, irreverente, que sea capaz no sólo de ver el mundo con los ojos de los revolucionarios sino también de trascender esa mirada, despegarse de ella y ver lo que esos ojos no pueden ver; un abordaje que interpele a sus propias fuentes, que sepa desconfiar de ellas, puede —al menos en este caso, aunque lo más probable es que en otros tambiéndiscernir proyecciones imaginarias, por empáticas que nos resulten, de realidades históricas que no pueden reducirse nunca a ellas puesto que - aun con independencia de datos empíricosimplican procesos complejos que resultan de la interacción de múltiples sujetos y de variadas intencionalidades en pugna. Y, en consecuencia, sólo un abordaje tal puede constituir argumento y prueba para que la disparidad y la diferencia históricas entre la violencia represiva y la revolucionaria encuentre su paralelismo en el campo jurídico; máxime en una sociedad en la que la voz de la Justicia ha marcado, en buena medida, los tiempos, el tono y el lenguaje de la memoria social.

Por añadidura, en el caso particular que nos ocupa, sólo aquellas intervenciones que desafiando el poder de veto realmente existente se adentren en el estudio de uno de los temas tabú por excelencia, el de la "justicia revolucionaria" — cuyas prácticas más conflictivas fueron los secuestros extorsivos y las ejecuciones selectivas de personas - pueden ofrecer argumentos tendientes a demostrar, a través de la investigación empírica y el análisis riguroso, que es más plausible, en relación al hecho que se juzga (esto es, la muerte de Larrabure), que la verdad se encuentre en boca del PRT-ERP y no en la de los deudos del militar. Dicho en otras palabras, que la organización guerrillera ni torturó a Larrabure (porque la guerrilla argentina no tortura), ni lo mató (porque cuando mata, justamente porque lo considera un acto de justicia, lejos de negarlo, lo reivindica).

En fin, el caso Larrabure, nos invita no sólo a repensar el complejo vínculo entre Historia y Justicia, también a redoblar la apuesta por una historiografía crítica de las izquierdas, aunque más no sea en el más elemental y modesto gesto del oficio: la distancia entre objeto y sujeto de conocimiento. Está claro que esa criticidad puede no ser exclusiva de la cultura de izquierdas, pero es, en todo caso, su condición sine quanon.

V. C.

\section{Memorias para los feminismos}

Así como la acción de apertura del Teatro Cervantes en 2018 tomó a Marx como referencia, el 2019 abrió con una Asamblea de Mujeres que retomaba el título de aquella vieja obra de Aristófanes. A la hora del cierre, que compartimos con Diana Maffía y Rita Segato, la sala no podía estar más colmada ni más verde. El programa de todo el día había intentado — no sin una esperable cuota de fracaso- captar todas las inflexiones del deseo y la identidad, con el objetivo de demostrar que la asamblea del siglo XXI debe ser diversa, disidente, y plural en voces y cuerpos.

El panel final nos propuso responder la pregunta "¿Cómo vivir juntes?", un interrogante que sonaba algo paradójico bajo un gobierno en el cual las condiciones de vida fueron cada vez más precarias y excluyentes. Porque, a pesar de su reconocida autonomía, el Cervantes no dejaba de ser un teatro de gestión estatal y, por tanto, resultaba pertinente responder con una crítica explícita a las formas de vida propuestas a fuerza de profundizar el neoliberalismo y sus verdades. Una suma de eslóganes entre cuyos 
supuestos básicos está la idea de que una comunidad de iguales (aunque diversos) se construye a puro presente, sin las pesadas cadenas ideológicas del pasado, arrasando el pasado, y limando diferencias para rejuntarlas en un voluntarioso "juntes".

Cuanto todo eso fue dicho, Susy Shock puso la música final y esa ternura indómita que le es tan propia. A la salida alguien dijo entre lágrimas: "son tiempos nuevos"; otra emocionada agregó: es una "revolución joven". Representaban la misma sensación que recorre las sobremesas familiares, las salas docentes o las oficinas, y que las revistas de los diarios sintetizan con la frase "el feminismo está de moda". Ante esa observación que no deja de ser algo cierta, sostener Políticas de la Memoria se convierte en una tarea fundamental. Cuando las calles, paredes y remeras cantan "ahora que sí nos ven", quieren decir un poco esto: hemos estado siempre. Antecedentes para el feminismo, sobran. Ancestras las hay por decenas. Es por esa historia densa que da base al presente que estallan innumerables libros y artículos; que a las instituciones les crecen secretarías y áreas donde no habían querido mirar; que una semana de agenda porteña tiene apuntadas tres actividades feministas el mismo día. En suma, la ola no es la imagen de algo que irrumpe donde había calma, sino de una fuerza descomunal que arrasa los sentidos comunes e inunda el presente con su vieja potencia contenida.

Darse políticas de la memoria es, para empezar, combatir el puro presente, el estallido por hartazgo, la incandescencia de lo pasajero. Luego construir genealogías, sacudir los cánones, diversificar panteones, revisar a los consagrados, disputar tradiciones, recuperar voces, avivar debates y reescribir como nunca. Los índices de esta misma revista dan cuenta de esa línea de intervención que pretende poner en contacto crítico el pasado y el presente. No con afán de buscar lecciones ni establecer nuevos santorales, sino con la certeza de que saberse participante de un diálogo previo, fortalece, y que reconocerse como parte de un debate histórico, inspira. Ese impulso está detrás de los artículos publicados sobre periódicos anarcofeministas, las biografías de mujeres en lucha, la correspondencia de escritoras con causa, la carta callejera de una lesbiana decidida, las recepciones diversas del feminismo europeo, los documentos de las organizaciones armadas y las biografías de los grandes intelectuales tamizados por la mirada feminista, la revolución y la utopía pensadas desde la literatura de Úrsula K. Le Guin, las problemáticas relaciones entre la militancia y la subjetividad, las utopías y el amor, las peripecias políticas y literarias de ensayistas, poetas y maestras, y muchas escrituras más.

Años antes, otra revista nacida en la misma casa, El Rodaballo, pulsaba el debate teórico y político del feminismo, en esos años que van de mediados de los noventa a los primeros años del kircherismo, pasando por las jornadas del 2001. Al mismo tiempo, el acervo del $\mathrm{CeDInCl}$ crecía bajo la certeza de que había que abrir su condición de "archivo de izquierdas" a las expresiones emancipatorias de toda laya y a los movimientos sociales diversos. Así se preservaron materiales ligados a los Encuentros Nacionales de Mujeres, la lucha por el aborto legal, el activismo gay, los derechos humanos, etc.. La casa de Flores supo albergar el paso fugaz de un Grupo de Estudios Feministas que anunciaba sus variadas actividades en el número del año 2006. Aquella saga tomó forma más explícita diez años después cuando se creó el Programa de Memorias políticas feministas y sexogenéricas presentado en el número de 2017 con un artículo de María Luisa Peralta y dos documentos inéditos sobre las memorias de los activismos LGTB. El Programa tomó por nombre breve "Sexo y revolución", la frase que selló la política de rebelión y deseo que enarboló el Frente de Liberación Homosexual en los tempranos setenta.

Por último, trabajar las memorias como políticas y las políticas con sus memorias, no es un ejercicio de exoneración de las izquierdas. Al contrario, implica enfrentar con audacia crítica las aristas patriarcales que las atraviesan. $Y$ recordar que, sin bien hay en sus arcones plumas misóginas y heteronormadas, también guardan discursos que han agitado siempre la potencia de la subjetividad y del deseo cuando se sueña con transformar el mundo. Es nuestra tarea hacerlos presentes, volverlos disponibles y, sobre todo, combatir desde allí la utopía liberal con su diversidad publicitaria, individualista y deshistorizada.

L. F. C. 